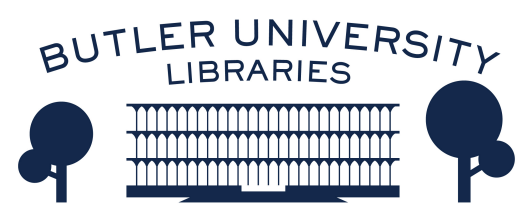

Journal of Hindu-Christian Studies

Volume 19

Article 8

January 2006

\title{
The Catholic Case: The Index of Prohibited Books
}

Daniel P. Sheridan

Follow this and additional works at: https://digitalcommons.butler.edu/jhcs

Part of the Religion Commons

\section{Recommended Citation}

Sheridan, Daniel P. (2006) "The Catholic Case: The Index of Prohibited Books," Journal of Hindu-Christian Studies: Vol. 19, Article 8.

Available at: https://doi.org/10.7825/2164-6279.1363

The Journal of Hindu-Christian Studies is a publication of the Society for Hindu-Christian Studies. The digital version is made available by Digital Commons @ Butler University. For questions about the Journal or the Society, please contact cbauman@butler.edu. For more information about Digital Commons @ Butler University, please contact digitalscholarship@butler.edu. 


\title{
The Catholic Case: The Index of Prohibited Books
}

\author{
Daniel P. Sheridan \\ St. Joseph's College of Maine
}

SOMETIMES it takes a while for the word to get out, or for it to get in. It has been said that, in India in 1948 as the British were leaving, there were villages that had not yet heard that they had arrived. Similarly, there may be villages in Tibet that have not yet heard that the Dalai Lama fled Tibet in 1959. Deep in Siberia in the mid 1930's, there were communities of Old Believers who did not know of the October Revolution in 1917. Googooling the words, "Index of Prohibited Books," resulted in more than a million references. A perusal of the first seven entries revealed that none took any note that the Roman Catholic Index of Prohibited Books had been terminated in 1966, forty years before 2006. Similarly, the same perusal does not reveal the reasons why the Catholic Church abandoned what to many outside the Church had seemed one of its negative defining features, nor the reasons why the Church has become one of the world's greatest defenders of a freedom of religion that precludes the prohibiting, censoring, and banning of books.

So the first piece of information to be presented here is that the Index no longer functions for Catholics to prohibit the reading of certain books. However, the history within the Roman Catholic Church of the Index Librorum Prohibitorum, ${ }^{\text {Ixix }}$ The Index of Prohibited Books, from 1557 to 1966, a period of 409 years, is related to the issues of book banning [prevention of publication] and censorship [review, revision, and pre-approval before publication] that are being discussed as part of the Society for Hindu -Christian Studies" panel on "Book Banning and the Spectacle of Censorship in Hinduism and Christianity." Of course, book banning and censorship lead to the broader theme of freedom of thought and of freedom of religion.

The Index was very much a phenomenon of the age of print literacy and publication. In the world-historical pre-modern period which ended with the invention of printing in 1453 , literary works conveyed by an oral/memory tradition and books in manuscript were not able to be widely disseminated and read, were not available because not "published," and thus were seldom prohibited from being heard or read. A precision is in order here: the Index of Prohibited Books was a list of books that were not to be read by faithful Catholics. Thus Index neither banned nor censored books, although the Church did engage in prior censorship of books by its members and did attempt occasionally to prevent the publication of books. The Index was under severe challenge both from within and without the Church for at least its last two hundred years. It was also extensively defended in apologetics. ${ }^{1 \times x}$ For all of controversy around it, the Index was only published in Latin at the Vatican, and thus had relatively limited

DANIEL P. SHERIDAN, PH.D. (Fordham University), is Vice President for Academic Affairs and Dean of the College of Saint Joseph's College of Maine, U.S.A., and Professor of Theology. His field is History of Religions/Comparative Theology, within which he specializes in the religious traditions of India that were expressed in the Sanskrit language, namely Hinduism and Buddhism. Dr. Sheridan is also participating in the development within the Roman Catholic community of Comparative Theology (Theology of Religions) and in inter-religious dialogue informed by the History of Religions. He has published extensively in many leading academic journals. 
circulation. Its celebrity came as much from its mere existence as an indicator of magisterial displeasure than from its effectiveness in preventing certain books from being read. The Index was finally abolished by Pope Paul VI in 1966 since it was considered to be contrary to the teaching of Vatican Council II concerning freedom of inquiry (see Gaudium et Spes, \#62: "let it be recognized that all the faithful, clerical and lay, possess a lawful freedom of inquiry and thought, and the freedom to express their minds humbly and courageously about those matters in which they enjoy competence" ${ }^{\text {"xxi }}$ ).

In this presentation I will survey the Index's history as well the reasons for its demise. A quick description of the Index is in order. In the last edition of 1948, 4,126 books were listed that were published from 1600-1948. From 1600-1699, 1,331 books were listed; from 1700-1799, 1,186 books; from 1800-1899, 1,354; and from 1900-1948, 255 books. The books, listed in alphabetical order, are primarily theological, although novels, biographies, historical works, and travelogues are included. Books most often prohibited were usually written in Latin, Italian, and French, secondarily in English and German; there was even one book in Arabic. This distribution reflects the internal concerns of the Church about threats to the Church in Counter-Reformation Italy and France. The great founders of Protestantism, Martin Luther and John Calvin, were not included, since their works had already been condemned. The focus of books prohibited shifted in each of the four centuries that the Index existed. Eventually books by four American authors are listed: John William Draper, History of the Conflicts Between Religion and Science; George Zurcher, Monks and Their Decline; Telesphor Smyth-Vaudry, The Christ-Founded Order of the Secular Priesthood; and William L. Sullivan, The Priest, A Tale of Modernism and Letters to His Holiness, Pope Pius X, these last in 1912; only seven books in English were listed in the twentieth century.

For the pre-print era, the banning or prohibiting of the dissemination of books in the Church has a long history. The first instances are connected with the establishment of the canon of the Sacred Scriptures, the exclusion from which led to the virtual disappearance of several second and third century "gospels." These gospels have been recently attracting a lot of interest and have been called, anachronistically, the "Lost Books" of Christianity, ostensibly suppressed by a suffocating patriarchy. Instead it might be more accurate to say that they are "texts that died a natural death." For example, the Muratorian Canon (c. A.D. 170) was a determination of the authentic books of the New Testament and excluded others from liturgical usage. The specific banning of theological books also arose from the intense theological controversies of the patristic age. Pope Anastasius (d. 401) condemned the works of Origen (c.185-c.254), a hundred and fifty years after his death. This condemnation led to the disappearance of many of the works of one of the most significant of Christian theologians who had been considered perfectly orthodox within his lifetime. A decree issued by Pope Gelasius in 496 and published at a council in Rome has been loosely called the first "Index of Forbidden Books." The Gelasian Decree is divided into three parts: a list of authentic scriptural books, a number of recommended readings, and a list of apocryphal and heretical books. The following are further examples of early prohibitions: in 548 -Pope Vigilius condemned the "Three Chapters"; in 589 the Council of Toledo condemned books on Arianism; in 649 Pope Martin I forbade the writings of the Monothelites; in 855 the works of Scotus Erugina were proscribed; and in 869 Pope Adrian II burned the works of Photius.

With the rise of scholasticism in the medieval universities, a more open and confident spirit prevailed. The philosophical works of Greek antiquity and many Muslim works in Arabic were translated and widely read. Theological and philosophical works began to be distinguished from each other. A wider circulation of books enabled them to be compared and contrasted in the university libraries. For example, in the twelfth century Abelard's famous Sic et Non surveyed the various opinions and judgments of earlier Christian theologians and emphasized their differences. Putting all of these differences together in one book was at first a scandalous revelation of differing modes of thinking and 
expression. The scholastic method of contrastive and dialectical argument for a time brought order to the apparent disorder of differing theological and philosophical judgments. For example, Saint Thomas in the Summa Theologiae confidently cites hundreds of authors, and carefully distinguishes and weighs their different judgments before establishing his own conclusions. Yet with the breakdown of the medieval synthesis in the fourteenth and fifteenth centuries, books were again banned. For example, the works of John Wyclif were banned as heretical in 1415 in England, and those of John Hus in 1418 in Bohemia

The invention of moveable type in 1453 created a vastly new situation, and accelerated religious and social change. Because books now had a more extensive circulation, and thus because of a wider readership, they had a greater influence. Witness the role of printed books in both the Renaissance and the Reformation, especially that of the Bible. The widespread reading of newly printed translations and interpretations of the Bible enhanced the rapid rise and spread of the Reformation across northern Europe. Because of printing, the works of Martin Luther were read up and down Germany within weeks of their being written. At first the reaction of the Catholic Church was confused and ineffective, but as the CounterReformation gathered strength one of its tactics was the suppression of dangerous books, especially in the countries of southern Europe that remained in the Catholic orbit.

The first Index of Prohibited Books was established in 1557 by Pope Paul IV in the middle of the Counter-Reformation, as a list of books that Catholics were prohibited from reading on pain of excommunication. ${ }^{\text {lxxii }}$ The books were prohibited because they putatively contained material considered dangerous or contrary to the faith or morals of the reader. Paul IV entrusted the Congregation of the Inquisition, later known as the Holy Office, with the task of drawing up and maintaining this list of prohibited books. This first list was ready in the same year, but not meeting with the Pope's approval, was never published. A second attempt produced a larger, more complete Index, published in January 1559. This was the first general Roman Index published to carry the title
"Index." The work, known as either the Tridentine Index or the Index of Pius IV, was published in 1564. Pope Alexander VII published another edition of the Index in 1664. This was the first papal index to list all books alphabetically by author. In 1757 Pope Benedict XIV promulgated the revised Index, the best edition published up to that time. From 1758 to 1897 all the editions of the Index published were simply reprints of Benedict's edition, each adding works prohibited since the preceding edition.

As a result of the Enlightenment, the French Revolution, and the emergence of modernity, the Catholic Church in Europe was in a particularly embattled state. Thus there was simultaneously both a growing public scandal and disrepute associated with the Index of Prohibited Books and, at the same time, an intensified extension of its use. This is indicated by the breath and prominence of the books and authors proscribed from the seventeenth to the end of the nineteenth centuries: Descartes, Pascal, Bacon, Montesquieu, Voltaire, Rousseau, Kant, Gibbon, Locke, Bentham, Acton, Mill, Renan, Lamenais, Hugo, Dumas pere and fils, Comte, and Zola. Remarkably, the works of Copernicus, Galileo, Hegel, Darwin, and Marx were never included. The listing of novels especially came to appear silly and typically reactionary to the progressive Protestant countries of northern Europe.

Many of the bishops at the Vatican Council I (1870) requested a revision of the entire Index legislation. Unfortunately, because of the outbreak of the Franco-Prussian War, the Council adjourned before this matter could be discussed. Shortly thereafter, however, Pope Leo XIII presented the Church a new edition of the Index with legislation supposedly adapted to the changed and varied needs of the time. The general norms governing the list were promulgated on January 25,1897 , and the new Index was published on September 17, 1901. The Index compiled by Leo XIII underwent several later editions, the latest and last being that of 1948 , by which time there were more than 4,000 titles on the Index. It gradually became the policy of the Church to restrict the number of books explicitly condemned and to depend on the more general principles 
prohibiting the reading of books deemed harmful. In fact, in the twentieth century, the threat to put a book on the Index was as effective a means of controlling theological developments as actually listing the book.

In the aftermath of the Modernist crisis in the early twentieth century, the bitter controversies that arose from the intensified effort to suppress open investigation and inquiry in theology, biblical studies, and philosophy drew attention to the appropriateness or inappropriateness of the Index of Prohibited Books as part of the Church's apostolic mission within modernity. In the 1940 s and the 1950 s the use of, and the threat of the use of, the Index played a key role in the "silencing" of such important theological figures as MarieDominique Chenu, Yves Congar, Henri de Lubac, Pierre Teilhard de Chardin, and Henri Bouillard. Following the publication of the encyclical Humani Generis in 1950 by Pope Pius XI the threat of being placed on the Index was particularly effective. Vatican Council II reversed the "silencing" with a "rehabilitation" of these theologians. Several of these theologians played important roles at the Council. Two of them, Yves Congar and Henri de Lubac were later named Cardinals. It is now known that the future popes, John XXIII and Paul VI, were disturbed by these efforts at theological retrogression. In 1959 Jean Steinmann's La Vie de Jesus had the dubious distinction of being the last work placed on the Index of Prohibited Books. As late as the spring of 1962, however, there was an attempt to place on the Index Henri de Lubacs's The Religious Thought of Teilhard. Pope John XXIII personally vetoed this attempt.

The Second Vatican Council from 19611965 brought all of this to a halt. It signified the end of the Counter-Reformation, and thus the end of the era of the Index. In Fr. John Courtney Murray's words, the Council conducted "the greatest argument on religious freedom in all history." In the context of the freedom of religion from external coercion by government, the necessity for a freedom to read within the Church became exquisitely clear. The Council's Declaration on Religious Freedom, Dignitatis Humanae, opens with this emphatic statement:

\begin{abstract}
"The religious acts whereby men, in private and in public, and out of a sense of personal conviction, direct their lives to God transcend by their very nature the order of terrestrial and temporal affairs. Government, therefore, ought indeed to take account of the religious life of the people and show it favor since the function of government is to make provision for the common welfare. However, it would clearly transgress the limits set to its power were it to presume to direct or inhibit acts that are religious . . . in spreading religious faith and introducing religious practices, everyone ought at all times to refrain from any manner of action which might seem to carry a hint of coercion or of a kind of persuasion that would be dishonorable or unworthy."
\end{abstract}

What may be true for external civil government and society may also be true for the internal religious government and society of the Church. The thinking that lay behind the Declaration on Religious Freedom had a profound influence on all areas of Church thinking. It especially occasioned a rediscovery of a basic premise of Catholic faith. In the words of Robert Drinan, "Even if the decree was slow in coming, the Church's statement repudiating the use of any kind of coercion to advance the faith was a cause for rethinking and rejoicing by Catholics. The acceptance of everyone's individual freedom to religious choice made sense of every theological norm used throughout the ages of faith. It is elementary in Catholic teaching that faith is a gift given gratuitously by God to those whom God chooses. No human effort can merit faith or expedite its coming." "xxiii

Hence, in the debates of Vatican II, the purpose and effectiveness of the Index of Prohibited Books came under intense scrutiny as part of a review of the role of the Holy Office in the light of a new emphasis on human dignity, Christian humanism, and religious freedom. Cardinal Frings, Archbishop of Cologne, intervened eloquently in the aula of Saint Peter's, pleading for a reform of the Holy Office that would include ending of the Index of Prohibited Books: the methods of the Holy 
Office "are out of harmony with modern times and a cause of scandal to the world." ${ }^{\text {"lxxiv }}$ For his written draft, Cardinal Frings was assisted by Fr. Joseph Ratzinger, who in an interesting twist later became the Prefect of the Congregation of the Doctrine of the Faith, and in 2005 was chosen Pope Benedict XVI. Finally, in 1966, Cardinal Alfredo Ottaviani, the head of the newly named Congregation of the Doctrine of the Faith, at the prodding of Pope Paul VI, declared that there would be no more editions of the Index; as such it remains only a historical document. The new Code of Canon Law, promulgated in 1983, continues to try to protect the faithful from dangerous writings, but the developments of Vatican II regarding the freedom of inquiry are preserved. The new Code includes in Book III, The Teaching Function of the Church, Title IV, Instruments of Social Communication and Books in Particular. This section deals with the prior censorship of a very narrow range of official publications. These canons are subordinate to canons 211, and especially to 212 , which states that "According to the knowledge, competence, and prestige which they possess, they [the faithful] have the right and at times the duty to manifest to the sacred pastors their opinion on matters which pertain to the good of the Church and to make their opinion known to the rest of the Christian faithful, without prejudice to the integrity of faith and morals, with reverence toward their pastors, and attentive to common advantage and the dignity of persons."

I think it is in order to note that the Index was not about "scholarship" in its contemporary understanding. However, the rise of scholarship in this understanding within the Church was one of the contributing reasons for the demise of the Index. To conclude on this note, let me cite Pope John Paul II: "It is the honor and responsibility of a Catholic University to consecrate itself without reservation to the cause of truth. This is its way of serving at one and the same time both the human dignity and the good of the Church, which has an intimate conviction that truth is (its) real ally .... And that knowledge and reason are sure ministers to faith' [J. H. Newman, The Idea of a University]. Without in any way neglecting the acquisition of useful knowledge, a Catholic University is distinguished by its free search for the whole truth about nature, man and God." $\mathrm{He}$ also affirmed, "The Church, accepting, 'the legitimate autonomy of human culture and especially of the sciences,' recognizes the academic freedom of scholars in each discipline in accordance with its own principles and proper methods, and within the confines of the truth and the common good." ${ }^{\mathrm{xxv}}$ Thus, positive reasons for the negative termination of the Index of Prohibited Books resonate far beyond the boundaries of Roman Catholicism. ${ }^{\text {xxvi }}$ Surely, the "free search for the whole truth about nature, man and God," a search which prohibits the prohibiting of books and of scholarship, should be recognized by all forms of Christianity and of Hinduism, and by people of good will everywhere.

lxix Index Libromum Prohibitorum (Vatican City: Typis Polyglottis Vaticanis, 1948). This is the last published edition.

${ }^{1 \mathrm{xx}}$ See Francis S. Bettin, S.J., The Roman Index of Forbidden Books (St. Louis: Herder and Herder, 1920) and Redmond A. Burke, C.S.V., What is the Index? (Milwaukee: Bruce Publishing Company, 1952).

lxxi "Gaudium et Spes," \#62, in The Documents of Vatican II, ed. Walter M. Abbott, S.J., (New York: Guild Press, 1966).

lxxii In the Roman Catholic Church, excommunication means exclusion from the sacraments and the exercise of full rights in the church.

Excommunication either follows automatically from certain acts or is pronounced by a church tribunal or authority.

lxxiii Robert F. Drinan, S.J., Can God \& Caesar Coexist? Balancing Freedom \& International Law (New Haven: Yale University Press, 2004), p. 110. lxxiv George Weigel, God's Choice: Pope Benedict $X V I$ and the Future of the Catholic Church (New York: Harper Collins, 2005), p. 170.

${ }^{1 x x v}$ Pope John Paul II, Ex Corde Ecclesiae, \#4 (Washington, D.C.: United States Catholic Conference, 1990), pp. 5-6.

Ixxvi See United Nations Declaration on the Elimination of All Forms of Intolerance and of Discrimination Based on Religious Belief (1981): “ the right to freedom of thought, conscience, religion or belief shall include, inter alia, the following freedoms ... (d) To write, issue and disseminate relevant publications in these areas ... (i) To establish and maintain communications with individuals and communities in matters of religions or belief at the national and international levels." 